\title{
Design and Evaluation of 1,7-Naphthyridones as Novel KDM5 Inhibitors
}

Sharada S. Labadie ${ }^{\star a}$, Peter S. Dragovich ${ }^{a}$, Richard T. Cummings ${ }^{b}$, Gauri Deshmukh $^{\mathrm{a}}$, Amy Gustafson ${ }^{\mathrm{a}}$, Ning $\mathrm{Han}^{\mathrm{c}}$, Jean-Christophe Harmange ${ }^{\mathrm{b}}$, James R. Kiefer ${ }^{\mathrm{a}}$, Yue Li ${ }^{\mathrm{c}}$, Jun Liang ${ }^{a}$, Bianca M. Liederer ${ }^{a}$, Yichin Liu ${ }^{a}$, Wanda Manieri ${ }^{b}$, Wiefeng $\mathrm{Mao}^{\mathrm{c}}$, Lesley Murray $^{\mathrm{a}}$, Daniel F. Ortwine ${ }^{\mathrm{a}}$, Patrick Trojer ${ }^{\mathrm{b}}$, Erica VanderPorten ${ }^{\mathrm{a}}$, Maia Vinogradova ${ }^{\mathrm{a}}$, Li Wen ${ }^{c}$

${ }^{a}$ Genentech Inc., 1 DNA Way, South San Francisco, California 94080, USA

${ }^{\mathrm{b}}$ Constellation Pharmaceuticals Inc., 215 First Street, Suite 200, Cambridge, MA 02142, USA

'Wuxi Apptec, 288 Fute Zhong Road, Waigaoqiao Free Trade Zone, Shanghai, 200131, China 
Remodeling of chromatin triggered by DNA methylation and histone modifications plays a pivotal role in DNA replication, repair and regulation of transcription. ${ }^{1}$ Covalent epigenetic histone modifications include acetylation, methylation, phosphorylation and ubiquitination of select lysine or arginine residues. Dysregulation of epigenetic signatures has been implicated in tumorigenesis. ${ }^{2}$ Several inhibitors of DNA methyltransferases (DNMTs) and histone deacetaylases (HDAC) have been approved for clinical use in the treatment of hematological malignancies, providing proof of concept for epigenetic therapies. ${ }^{3}$ Recent studies have shown that the family of histone lysine demethylases (LSDs/KDMs) contributes to cancer cell proliferation, promotes drug tolerance, and maintains tumor initiating cells. ${ }^{4}$ Among these proteins, members of the KDM5 family, KDM5A and KDM5B, are overexpressed in multiple forms of cancer, including, breast, prostate, bladder, and lung ${ }^{5}$ Recently, a selective inhibitor of the KDM5 histone demethylase family was shown to dramatically reduce drug-resistant cancer cell populations.$^{6,7}$ Despite KDM5A playing a vital role in cancer cell treatment tolerance, only mild behavioral aberrations and hematological abnormalities have been observed in KDM5A knock-out mice. ${ }^{8}$ Collectively, this information suggests that inhibitors of KDM5A and/or KDM5B have potential to function as novel chemotherapeutic agents.

The Jumonji C-domain (JmjC) demethylases, of which KDM5 is a member, have been extensively reviewed. ${ }^{9}$ All family members catalyze the demethylation of histone lysine residues via a reaction dependent on both a catalytic iron (II) atom and consumption of the co-substrate 2 -oxoglutarate (2-OG). ${ }^{10}$ Accordingly, several ironchelating molecules (Figure 1) such as $\mathrm{NOG}^{11}(\mathbf{1})$ hydroxamic acids ${ }^{12}(2), 2,2-$ 
bipyridycarboxylic acid derivatives ${ }^{13}(3)$, GSK $\mathrm{J} 1^{14}(4)$, and pyridopyrimidinones ${ }^{15,16}$ (5a, b) have been identified as inhibitors of various JmjC family members. ${ }^{17}$ These compounds typically display potent biochemical inhibition potency for their intended targets but also inhibit other KDMs, and thus lack selectivity. We recently disclosed a new class of potent, 2-OG competitive, pan-KDM5 inhibitors exemplified by compound 6 $\left(\mathrm{IC}_{50}=0.01 \mu \mathrm{M}\right.$, Figure 1$)$ with selectivity over related $\mathrm{KDMs}^{7}$ In this report, we describe the identification of a novel KDM5 inhibitor series that is 2-OG competitive and structurally distinct.<smiles>O=C(O)CNC(=O)C(=O)O</smiles>

1<smiles>O=C(O)CCNc1cc(N2CCc3ccccc3CC2)nc(-c2ccccn2)n1</smiles>

4<smiles>O=C(CCCCCCC(=O)Nc1ccccc1)NO</smiles>

2<smiles>O=c1[nH]cnc2c(-n3cc(CCC4CCN(c5cc(Cl)cc(Cl)c5)CC4)cn3)nccc12</smiles>

$5 a$<smiles>COC(=O)c1ccnc(-c2cc(C(=O)O)ccn2)c1</smiles>

3<smiles>O=c1[nH]c(Oc2cnn(Cc3ccccc3)c2)nc2cnccc12</smiles>

$5 b$<smiles>CC(C)c1c(-c2ccccc2)[nH]c2c(C#N)cnn2c1=O</smiles>

6<smiles>O=c1[nH]c(C(F)(F)F)nc2cnccc12</smiles>

7

Figure 1. Previously disclosed inhibitors of histone demethylases and HTS hit 7. 
2-(Trifluoromethyl)pyrido[3,4-d]pyrimidin-4(3H)-one (7, Figure 1) was identified as a KDM5A inhibitor from a high-throughput screening campaign $\left(\mathrm{IC}_{50}=0.16 \mu \mathrm{M}\right)$. $\mathrm{A}$ nine-fold loss of potency was observed against KDM5A when 7 was assayed at high 2OG concentrations (10X) suggesting that the compound was a 2-OG competitive inhibitor. ${ }^{18}$ This molecule also showed encouraging selectivity for KDM5 relative to the $\mathrm{KDM} 4 \mathrm{C}\left(\mathrm{IC}_{50}=1.9 \mu \mathrm{M} ; 12\right.$-fold $)$ and $\mathrm{KDM} 2 \mathrm{~B}\left(\mathrm{IC}_{50}>25 \mu \mathrm{M} ;>150\right.$-fold $)$ isoforms. Overlapping of the HTS hit 7 onto the previously disclosed ${ }^{7}$ co-crystal structure of 6 bound to KDM5A (Figure 2a) suggested that the N-7 of the pyridine ring in 7 might bind to the active site iron atom and the ionizable pyrimidin- $4(3 \mathrm{H})$-one functionality (measured pKa of $7=4.6$ ) would produce favorable interactions with the nearby Lys501 and Asn575 residues. This analysis also indicated that the vector extending from the pyrimidin-4(3H)-one N-3 position protruded into a region of the KDM5 protein occupied by the isopropyl substituent of compound 6. As optimization of this position imparted significant potency enhancements to the compound 6 inhibitor series ${ }^{19}$, we were interested in elaborating compound $\mathbf{7}$ to seek similar potency gains. However, we were also concerned that alkylation of the pyrimidin-4(3H)-one N-3 position in 7 would abolish the hypothesized favorable interactions with the Lys501 and Asn575 depicted in Figure $2 \mathrm{~b}$ by eliminating the ionizable functionality in the resulting compound. Accordingly, we designed a hybrid naphthyridone ${ }^{20}$ inhibitor scaffold 8 that favorably combined portions of both compounds 6 and 7 . As shown in Figure $2 b$, the new design provides the ability to derivatize the naphthyridone C-3 position (analogous to N-3 of compound 7) while retaining the ionizable functionality deemed important for interactions with the polar sidechains of the Lys501 and Asn575 residues. ${ }^{7}$ Structure 8 also preserves a pyridine 
metal-binding substituent whose interaction with the iron were believed to be necessary for maintaining high binding affinity.

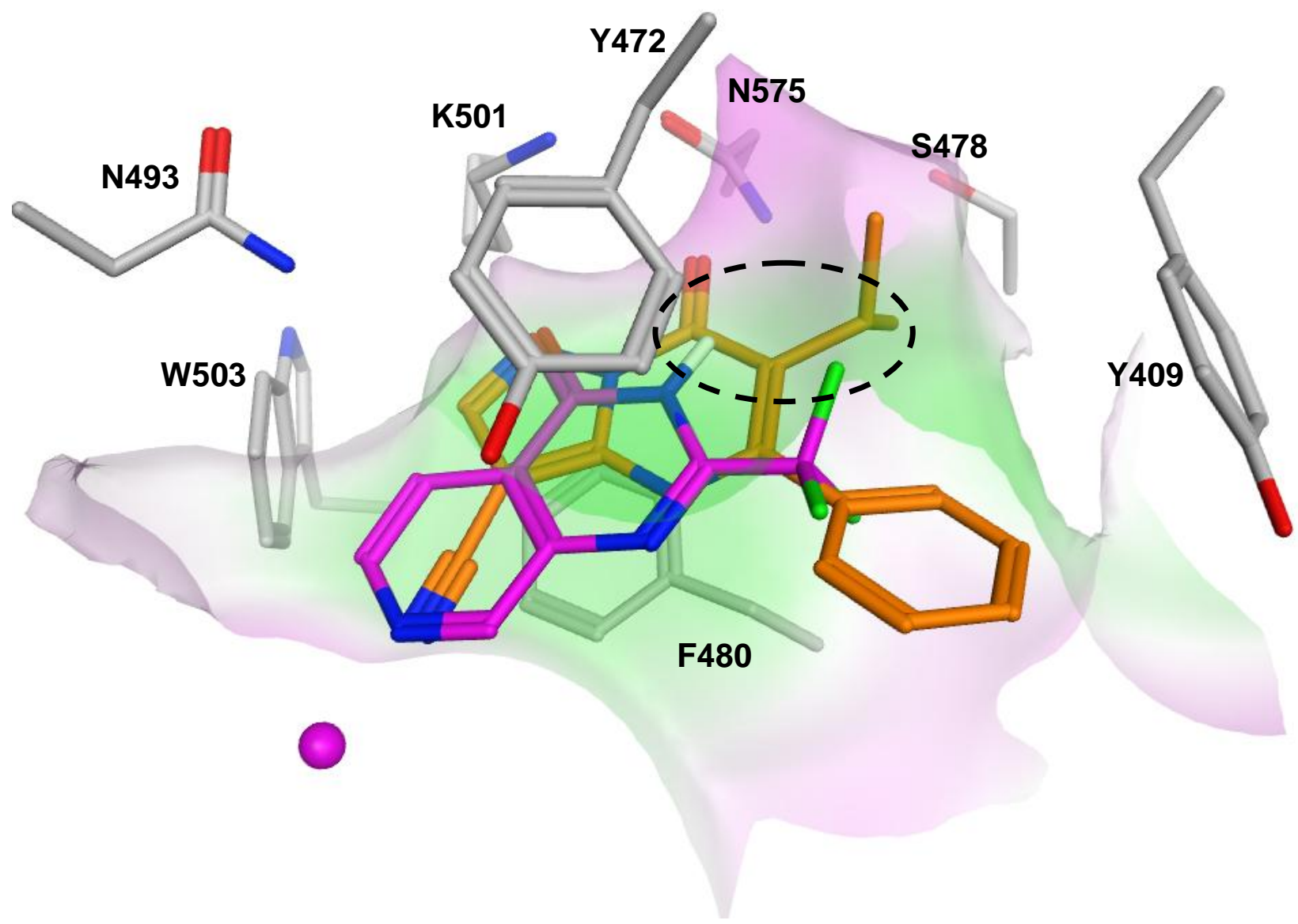

Figure 2a. Overlapping of the HTS hit 7 (pink) onto the co-crystal structure of 6 (orange) bound to $\mathrm{KDM}^{2} \mathrm{~A}^{7}$ (PDB code $5 \mathrm{CEH}$ ). Accessible space in the binding pocket adjacent to N-3 of the HTS hit 7 is shown with a black ellipse. 


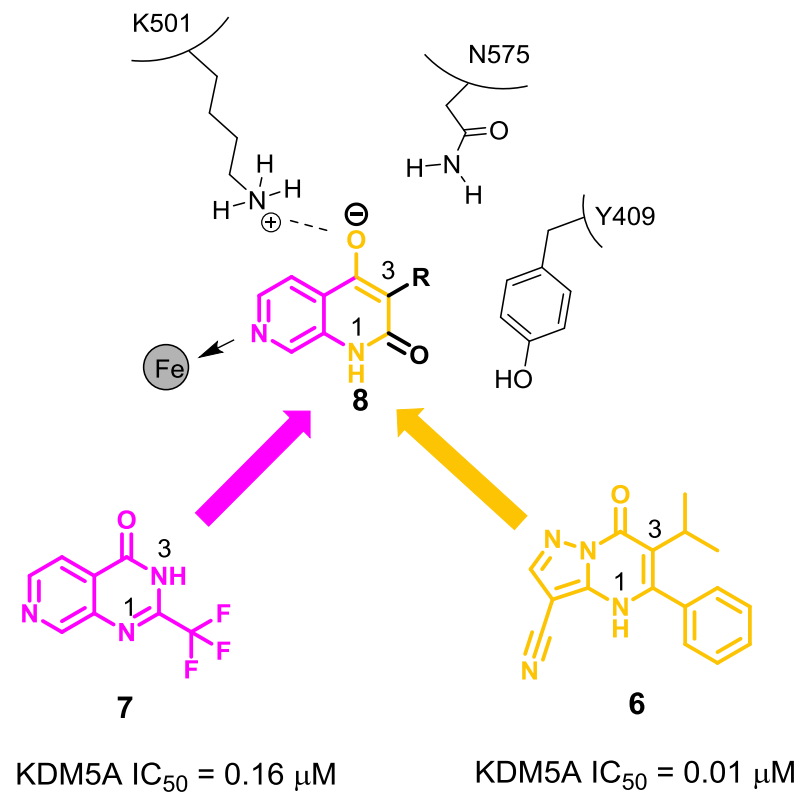

Figure 2b. Design of 1,7-naphthyridone KDM5 inhibitors.

As shown in Table 1, an initially synthesized 1,7-naphthyridone compound (9) displayed inhibition of KDM5A that was comparable to the pyrimidin-4(3H)-one 7 from which it was derived. As was observed for $\mathbf{7}$, and consistent with its hypothesized binding mode, use of higher 2-OG concentrations in the assay buffer diminished the biochemical potency of 9 (high 2-OG $I_{50}=2.1 \mu \mathrm{M}$ ). As anticipated from Figure 2a, removal of the ethyl substituent from the naphthyridone core resulted in a significant loss of KDM5A inhibition (10, Table 1). Compound 11, with ethyl groups at both $\mathrm{N}-1$ and $\mathrm{C}-3$ positions, lost considerable potency relative to 9 , indicating substitution on $\mathrm{N}-1$ was not tolerated possibly because of the exposure of this position to solvent. Attachment of electron withdrawing moieties to the naphthyridone C-3 position was then pursued to increase the ionizable character of the scaffold. These changes resulted in 
four- and nine-fold improvements in biochemical potency against KDM5A relative to 9 for an ester or a nitrile substituent (12 and 13), respectively. The biochemical potency enhancement was attributed to the improved interactions between the more acidic pyridone moiety (measured pKa of $12=4.1$ and $13=3.5$ ) and Lys501 and/or Asn575 sidechains. The de-aza analogs (14 and 15), and 8-aza analog (16) were also prepared and tested. ${ }^{21}$ These changes resulted in inhibitors with significantly diminished biochemical potency and indicated that the naphthyridone N-7 atom was likely involved in coordination to the Fe (II) species present in the KDM5A binding site. Compounds 12 and 13 exhibited substantial potencies against KDM5B and KDM5C, and were selective over KDM4C (Table 2). Compound 13 was also selective over KDM2B. Inhibitors 12 and 13 were tested in a PC9 cell-based assay to assess the changes in the levels of global histone 3 lysine 4 trimethylation (H3K4me3) since KDM5 enzymes were previously shown to specifically target $\mathrm{H} 3 \mathrm{~K} 4 \mathrm{me} 3$ for demethylation. ${ }^{22}$ Unfortunately, no change in global $\mathrm{H} 3 \mathrm{~K} 4 \mathrm{me} 3$ levels was observed at inhibitor concentrations up to $30 \mu \mathrm{M}$. The MDCK permeability of 12 was low $\left(0.7 \times 10^{-6} \mathrm{~cm} / \mathrm{s}\right)$ and that of 13 could not be measured. The lack of cellular activity was attributed to poor cell permeability of these compounds. The low permeability was hypothesized to be due the strong acidic nature of the pyridone moiety. Therefore, lowering the acidity by increasing the pKa of the ionizable proton was warranted. 
Table 1. Structure activity relationships of compounds 9-16.

\begin{tabular}{|c|c|c|c|c|c|}
\hline Ex. & Structure & $\begin{array}{c}\text { KDM5A } \\
(\mu \mathrm{M})^{\mathrm{a}}\end{array}$ & Ex. & Structure & $\begin{array}{c}\text { KDM5A } \\
(\mu \mathrm{M})^{\mathrm{a}}\end{array}$ \\
\hline 9 & & 0.23 & 13 & & 0.025 \\
\hline 10 & & 6.7 & 14 & & $>25$ \\
\hline 11 & & 3.8 & 15 & & $>25$ \\
\hline $12^{b}$ & & 0.06 & 16 & & $>25$ \\
\hline
\end{tabular}

${ }^{\mathrm{a}}$ For compounds with $\mathrm{IC}_{50}<100 \mathrm{nM}$, the biochemical inhibition data is the average of at least two separate runs. ${ }^{b} \sim 1: 1$ mixture of ethyl and methyl ester.

Table 2. Selectivity profile of 12 and 13.

\begin{tabular}{|c|c|c|c|c|}
\hline Ex & $\begin{array}{c}\text { KDM5B IC } \\
(\mu \mathrm{M})\end{array}$ & $\begin{array}{c}\text { KDM5C IC } \\
(\mu \mathrm{M})\end{array}$ & $\begin{array}{c}\mathrm{KDM} \text { 4C IC } \\
(\mu \mathrm{M})\end{array}$ & $\begin{array}{c}\text { KDM2B IC } \\
(\mu \mathrm{M})\end{array}$ \\
\hline 12 & 0.02 & 0.08 & 17 & $\mathrm{ND}$ \\
\hline 13 & 0.07 & 0.17 & $>25$ & $>25$ \\
\hline
\end{tabular}


Accordingly, a series of C-3 carboxamide analogs were synthesized. This also enabled the exploration of the binding pocket encompassed by Ser478 and Y409 with various alkyl substituents on the amide moiety (Table 3). The methyl and ethyl amides (17 and 18) were comparable to ester 12 in their biochemical potency. However, potency loss was dramatic with the isopropyl (19) and benzyl amides (20) indicating that the binding pocket was too small to accommodate larger alkyl substituents protruding from the amide $\mathrm{N}$-atom. Tertiary amides (21-23) were also synthesized, but these showed decreased potency compared to the secondary amides. The most potent of the amides, compound 18, displayed excellent MDCK permeability and other DMPK properties (Table 4) but did not show change in global H3K4me3 levels at inhibitor concentrations up to $30 \mu \mathrm{M}$ in the PC9 cell based assay. An analogous high cell to enzyme potency shift (500-fold) was observed with $6^{7,19}$ and has been reported for other KDM inhibitors. ${ }^{16}$ Although the reasons for the lack of cell activity for these 2-OG competitive inhibitors are not clear, the poor translation from enzyme to cell activity could be related to competing against high endogenous 2-OG concentrations. 
Table 3. Structure activity relationships of compounds 17-23.

\begin{tabular}{|c|c|c|c|c|c|}
\hline Ex. & Structure & $\underset{(\mu \mathrm{M})^{\mathrm{a}}}{\mathrm{KDM}}$ & Ex. & Structure & $\begin{array}{c}\text { KDM5A I } \\
(\mu \mathrm{M})^{\bar{a}}\end{array}$ \\
\hline $12^{b}$ & & 0.06 & 20 & & $>25$ \\
\hline 17 & & 0.07 & 21 & & 0.7 \\
\hline 18 & & 0.05 & 22 & & $>25$ \\
\hline 19 & & 0.4 & 23 & & 5.3 \\
\hline
\end{tabular}

${ }^{\mathrm{a}}$ For compounds with $\mathrm{IC}_{50}<100 \mathrm{nM}$, the biochemical inhibition data is the average of at least two separate runs. ${ }^{b} \sim 1: 1$ mixture of ethyl and methyl ester.

Table 4. In-vitro DMPK properties of 18.

\begin{tabular}{|c|c|c|c|c|c|}
\hline Ex & $\mathrm{pKa}^{\mathrm{a}}$ & $\begin{array}{c}\text { MDCK } P_{\text {app }} \mathrm{A}: B \\
\left(\times 10^{-6} \mathrm{~cm} / \mathrm{s}\right)\end{array}$ & $\begin{array}{c}\text { h_PPB } \\
(\%)\end{array}$ & $\begin{array}{c}\mathrm{HLM}(\mathrm{mL} / \mathrm{min} / \mathrm{kg}) \\
(\mathbf{m})\end{array}$ & $\begin{array}{c}\text { Kinetic } \\
\text { Solubility }^{\mathrm{b}}\end{array}$ \\
\hline $\mathbf{1 8}$ & 6.4 & 15.8 & 70 & 11.5 & 132 \\
\hline
\end{tabular}

\footnotetext{
${ }^{a}$ Measured pKa. ${ }^{b}$ Kinetic solubility was measured at pH 7.4 in PBS buffer.
} 
The X-ray crystal structure ${ }^{18}$ of compound 18 bound to the KDM5A active site (Figure 3) shows that the inhibitor indeed binds in the 2-OG site and forms a monodentate coordination of the naphthyridone N-7 atom to the catalytic metal. The bicyclic ring system of the naphthyridone participates in $\pi-\pi$ stacking interactions with the aromatic sidechains of Tyr472 and Phe480, similar to those observed in the KDM5A complex with $6{ }^{7}$ The $N \varepsilon$ of Lys501 forms a $3.2 \AA$ hydrogen bond with the carbonyl oxygen of the inhibitor C-3 amide. The low resolution of the structure precluded inclusion of solvent molecules in the active site in the refinement. While docking suggested potential interactions between $4-\mathrm{OH}$ and Lys501 sidechain, in the structure, $4.0 \AA$ separates the relevant atoms, thus no hydrogen bond is observed. The $\mathrm{N}$-ethyl substituent of the C-3 amide makes van der Waals interactions with the sidechains of Ser478 and Tyr409. The close proximity of this alkyl tail to these protein sidechains is consistent with the sharp reduction in potency seen for larger groups at this position. Compound 18 occupies approximately twice the volume of 2-OG or the pseudosubstrate NOG in the binding site. The 3-N-ethyl carboxamide tail protrudes into regions of the binding site that differ in sequence among many demethylase enzymes. The residue Y472 is replaced with leucine in KDM2B, which would disrupt the aromatic stacking with the inhibitor in that isoform. ${ }^{23,24}$ This difference is presumably responsible for the observed selectivity over KDM2B for compound 13. The residues that are directly contacting the substrate are conserved between KDM5A and KDM4C enzymes. ${ }^{7}$ However, a few subtle differences are present in the second shell of the amino acid residues that surround the active site binding pocket. ${ }^{25,26}$ These differences are apparently responsible for selectivity over KDM4C. A similar selectivity profile over 
KDM2B and KDM4C is also observed for $6 .^{7}$ The $\mathrm{N}-1$ position of the naphthyridone borders the solvent front and the substitution of this position with an ethyl group (compound 11) resulted in potency loss presumably due to hydrophobic group exposure to solvent. ${ }^{27}$

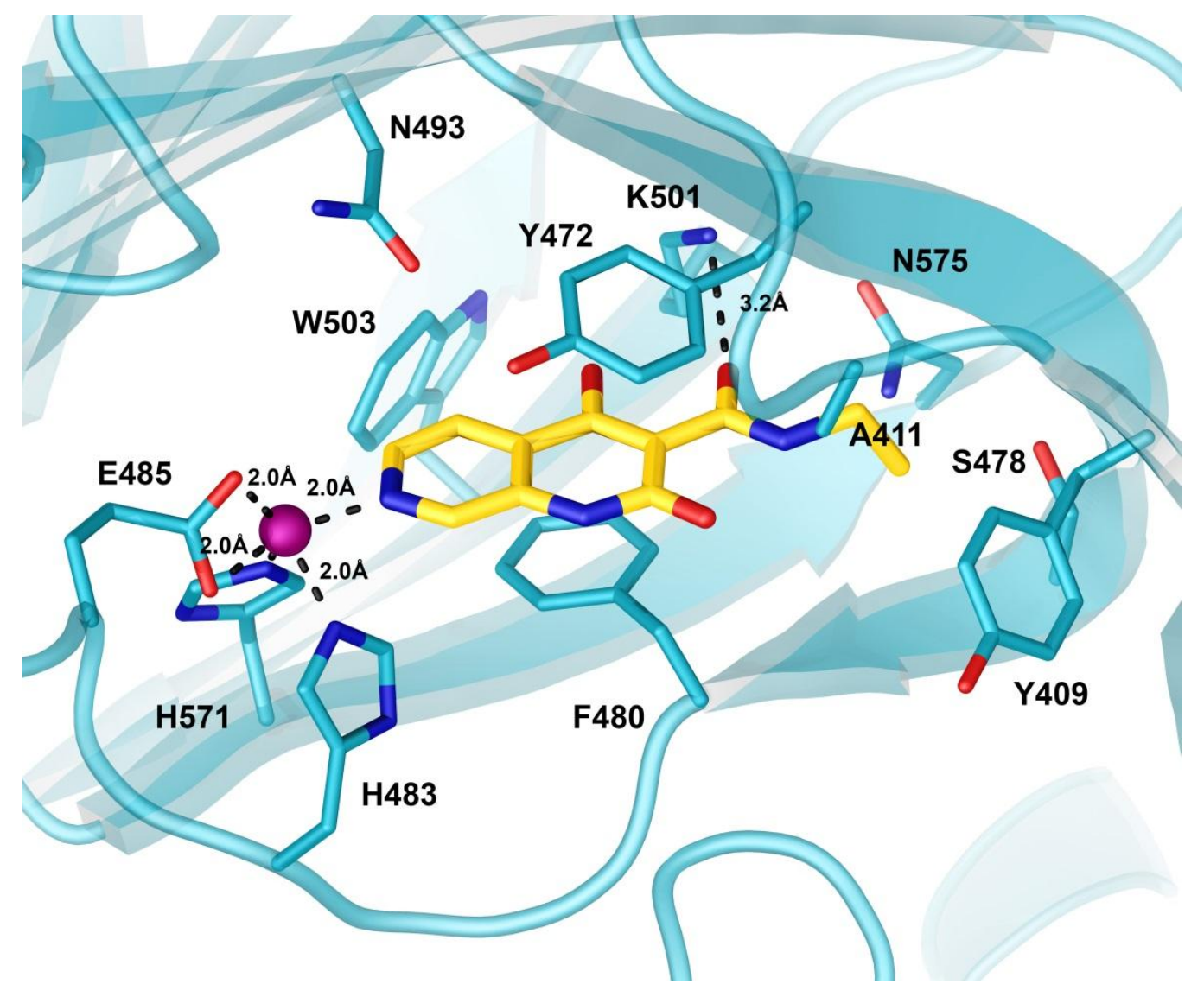

Figure 3. Crystal structure of $\mathbf{1 8}$ (gold carbons) bound at the KDM5A active site.

Sidechaains of amino acids coordinating the metal ion and those within $4.5 \AA$ of the inhibitor are shown as sticks, and the active site metal is depicted as a sphere (purple). Hydrogen bonds and metal interactions are shown as dashed lines.

In summary, we successfully combined the features from two distinct series to generate novel 1,7-naphthyridone-containing 2-OG competitive KDM5 inhibitors. These 
compounds were selective over KDM4C and KDM2B. Unfortunately, these inhibitors lacked cellular potency. The proposed 2-OG competitive binding mode of these novel KDM5 inhibitors was confirmed by obtaining an X-ray co-crystal structure of a representative molecule bound to KDM5A.

\section{Acknowledgements}

We thank Genentech Biomolecular Engineering for construct generation and protein expression and the staff at beamline 12.2 of SSRL for X-ray data collection setup. Use of the Stanford Synchrotron Radiation Lightsource, SLAC National Accelerator Laboratory, is supported by the U.S. Department of Energy, Office of Science, and Office of Basic Energy Sciences under Contract No. DE-AC0276SF00515. The SSRL Structural Molecular Biology Program is supported by the DOE Office of Biological and Environmental Research, and by the National Institutes of Health, National Institute of General Medical Sciences (including P41GM103393). The contents of this publication are solely the responsibility of the authors and do not necessarily represent the official views of NIGMS or $\mathrm{NIH}$. We also thank the Discovery Chemistry Small Molecule analytical group for their support.

Coordinates and structure factors for the crystal structure have been deposited at the RCSB with accession code $5 \mathrm{~K} 4 \mathrm{~L}$. 


\section{References and Notes}

1. Arrowsmith, C. H.; Bountra, C.; Fish, P. V.; Lee, K.; Schapira, M. Nat. Rev. Drug Discov. 2012, 11, 384.

2. You, J. S.; Jones, P. A. Cancer Cell, 2012, 9

3. Taberlay, P. C.; Jones, P. A. Prog. Drug Res. 2010, 67, 1.

4. (a) Højfeldt, J. W.; Agger, H.; Helin, K. Nat. Rev. Drug Discov. 2013, 12, 917. (b) Roesch, A.; Fukunaga-Kalabis, M.; Schmidt, E. C.; Zabierowski, S. E.; Brafford, P. A.; Vultur, A.; Basu, D.; Gimotty, P.; Vogt, T.; Herlyn, M. Cell 2010, 141, 583. (c) Catchpole, S.; Spencer-Dene, B.; Hall, D.; Santangelo, S.; Rosewell, I.; Guenatri, M.; Beatson, R.; Scibetta, A. G.; Burchell, J. M.; Taylor-Papadimitriou, J. Int. J. of Oncol. 2011, 38, 1267.

5. Rasmussen, P. B.; Staller, P. Epigenomics 2014, 6, 277.

6. Sharma, S. V.; Lee, D. Y.; Quinlan, M. P.; Takahashi, F.; Maheswaran, S.; McDermott, U.; Azizian, N.; Zou, L.; Fischbach, M. A.; Wong, K.-K.; Brandstetter, K.; Wittner, B.; Ramaswamy, S.; Classon, M.; Settleman, J. Cell 2010,141, 69.

7. Vinogradova, M.; Gehling, V. S.; Gustafson, A.; Williamson, K. E.; Arora, S.; Tindell. C.; Busby, J.; Wilson, C.; Manieri, W.; Gangurde, P.; Flynn, E. M.; Buker, S.; Kim, H. -j.; Lan, F.; Cochran, A. G.; Liu, Y.; Wongchenko, M.; Yang, Y.; Cheung, T.; Maile, T.; Lau, T.; Costa, M.; Hedge, G.; Jackson, E.; Pitti, R.; Guler, G. D.; Bailey, C.; Cummings, R. T.; Albrecht, B. K.; Harmange, J. -C.; Kiefer, J. R.; Trojer, P.; Classon. M. Nat. Chem. Biol. 2016, 12, 531. 
8. Klose, R. J.; Yan, Q.; Tothova, Z.; Yamane, K.; Erdjument-Bromage, H.; Tempst, P.; Gilliland, D. G.; Zhang, Y.; Kaelin, Jr. W. G. Cell 2007, 128, 889.

9. (a) Accari, S. L.; Fisher, P. R. Int. Rev. of Cell and Mol. Biol. 2015, 319, 165. (b) McAllister, T. E.; England, K. S.; Hopkinson, R. J.; Brennan, P. E.; Kawamura, A.; Schofield, C. J. J. Med. Chem. 2016, 59, 1308. (c) Park, S. Y.; Park, J.-W.; Chun, Y.-S. Pharmacol. Res. 2016, 105, 146.

10. Rose, N. R.; McDonough, M. A.; King, O. N. F.; Kawamura, A.; Schofield, C. J. Chem. Soc. Rev. 2011, 40, 4364.

11. Cloos, P. A.; Christensen, J.; Aggar, K.; Maiolica, A.; Rappsilber, J.; Antal, T.; Hansen, K. H.; Helin, K. Nature 2006, 442, 307.

12. Itoh, Y.; Sawada, H.; Suzuki, M.; Tojo, T.; Sasaki, R.; Hasegawa, M.; Mizukami, T.; Suzuki, T. Med. Chem. Lett. 2015, 6, 665.

13. Chang, K. -H.; King, O. N. F.; Tumber, A.; Woon, E. C. Y.; Heightman, T. D.; McDonough, M. F.; Schofield, C. J. ; Rose, N. R. ChemMedChem 2011, 6, 759.

14. (a) Kruidenier, L.; Chung, C.-w.; Cheng, Z.; Liddle, J.; Che, K. H.; Joberty, G.; Bantscheff, M.; Bountra, C.; Bridges, A.; Diallo, H.; Eberhard, D.; Hutchinson, S.; Jones, E.; Katso, R.; Leveridge, M.; Mander, P. K.; Mosley, J.; Ramirez-Molina, C.; Rowland, P.; Schofield, C. J.; Sheppard, R. J.; Smith, J. E.; Swales, C.; Tanner, R.; Thomas, P.; Tumber, A.; Drewes, G,; Oppermann, U.; Patel, D. J.; Lee, K.; Wilson, D. M. Nature, 2012, 488, 404. (b) Atkinson, S. J.; Barker, M. D.; Campbell, M.; Humphreys, P.; Liddle, J.; Sheppard, R. J.; Wilson, D.; Joberty, G. EP2592154 A1, 2013. 
15. Bavetsias, V.; Lanigan, R. M.; Ruda, G. F.; Atrash, B.; McLaughlin, M. G.; Tumber, A.; Mok, N. Y.; Bihan, Y.-V. L.; Dempster, S.; Boxall, K. J.; Jeganathan, F.; Hatch, S. B.; Savitsky, P.; Velupillai, S.; Krojer, T.; England, K. S.; Sejberg, J.; Thai, C.; Donovan, A.; Pal, A.; Scozzafava, G.; Bennett, J. M.; Kawamura, A.; Johansson, C.; Szykowska, A.; Gileadi, C.; Burgess-Brown, N. A.; von Delft, F.; Oppermann, U.; Walters, Z.; Shipley, J.; Raynaud, F. I.; Westaway, S. M.; Prinjha, R. K.; Fedorov, O.; Burke, R.; Schofield, C. J.; Westwood, I. M.; Bountra, C.; Müller, S.; van Montfort, R. L. M.; Brennan, P. E.; Blagg, J. J. Med. Chem. 2016, 59, 1388.

16. Westaway, S. M.; Preston, A. G. S.; Barker, M. D.; Brown, F.; Brown, J. A.; Campbell, M.; Chung, C.-w; Drewes, G.; Eagle, R.; Garton, N.; Gordon, L.; Haslam, C.; Hayhow, T. G.; Humphreys, P. G.; Joberty, G.; Katso, R.; Kruidenier, L.; Leveridge, M.; Pemberton, M.; Rioja, I.; Seal, G. A.; Shipley, T.; Singh, O.; Suckling, C. J.; Taylor, J.; Thomas, P.; Wilson, D. M.; Lee, K.; Prinjha, R. K. J. Med. Chem. 2016, 59, 1370.

17. Maes, T.; Carceller, E.; Salas, J.; Ortega, A.; Buesa, C. Curr. Opin. Pharmacol. 2015, 23, 52 .

18. See supporting information for experimental details.

19. Gehling, V. S.; Bellon, S.; Harmange, J. -C.; Leblanc, Y.; Odate, S.; Buker, S.; Lan F.; Sandy, P.; Bergeron, L.; Mao, W.; Gustafson, A.; Liu Y.; VanderPorten, E.; Trojer, P.; Albrecht, B. K. Bioorg. Med. Chem. Lett. accepted.

20. Related naphthyridones have been reported as the inhibitors of various therapeutic targets. (a) Sherlock, M. H.; Kaminski, J. J.; Tom, W. C.; Lee, J. F.; Wong, S.-C.; Kreutner, W.; Bryant, R. W.; McPhail, A. T. J. Med. Chem. 1988, 31, 2108. (b) Zhou, 
Z.-L.; Navratil, J. M.; Cai, S. X.; Whittermore, E. R.; Espitia, S. A.; Hawkinson, J. E.; Tran, M., Woodward, R. M.; Weber, E.; Keana, J. F. W. Bioorg. Med. Chem. 2001, 2061 (c) Fitch, D. M.; Colon, M. US 20070213335 A1.

21. A related de-aza compound has been assayed for activity against JRD1C (KDM5C; $\left.I_{50}>100 \mu \mathrm{M}\right)$ enzyme. Chowdhury, R.; Candel-Lena, J. I.; Chan, M. C.; Greenald, D. J.; Yeoh, K. K.; Tian, Y-M.; McDonough, M. A.; Tumber, A.; Rose, N. R.; Conejo-Garcia, A.; Demetriades, M.; Mathavan, S.; Kawamura, A.; Lee, M. K.; van Eeden, F.; Pugh, C. W.; Ratcliffe, P. J.; Schofield, C. ACS Chem. Biol. 2013, 8, 1488.

22. Black, J. C.; Whetstine, J. R. Biopolymers, 2013, 99, 127.

23. Chen, Z.; Zang, J.; Whetstine, J.; Hong, X.; Davrazou, F.; Kutateladze, T. G.; Simpson, M.; Mao, Q.; Pan,C.-H.; Dai, S.; Hagman, J.; Hansen, K.; Shi, Y.; Zhang, G. Cell 2006,125, 691 .

24. Han, Z.; Liu, P.; Gu, L.; Zhang, Y.; Li, H.; Chen, S.; Chai, J. Frontier Science 2007, 52.

25. Hillringhaus, L.; Yue, W.W.; Rose, N.R.; Ng, S.S.; Gileadi, C.; Loenarz, C.; Bello, S.H.; Bray, J.E.; Schofield, C.J.; Oppermann, U. J. Biol. Chem. 2011, 286, 41616.

26. Chu, C.-H. Wang, L.-Y.; Hsu, K.-C.; Chen, C.-C.; Cheng, H.-H.; Wang, S.-M.; Wu, C.-M.; Chen, T.-J.; Li, L.-T.; Liu, R.; Hung, C.-L.; Yang, J.-M.; Kung, H.-J.; Wang, W.-C. J. Med. Chem. 2014, 57, 5975.

27. Wong, S. E.; Lightstone, F. C. Expert. Opin. Drug. Discov. 2011, 6, 65. 


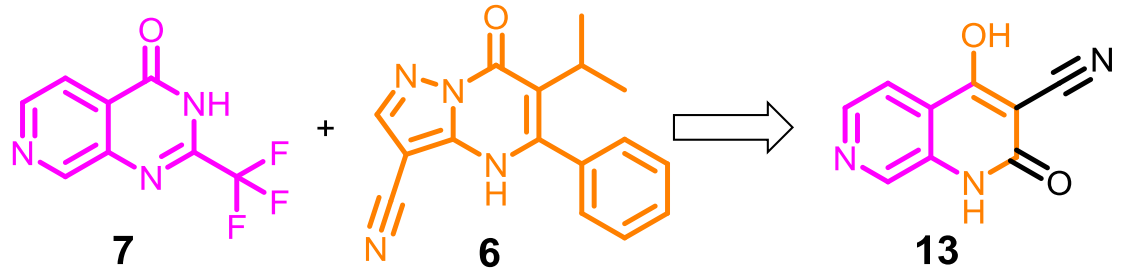

KDM5A IC 50

$0.16 \mu \mathrm{M}$

$0.01 \mu \mathrm{M}$

$0.025 \mu \mathrm{M}$ 